\title{
CONVENIENCE STORES AS AN URBAN CULTURE SPACE FOR YOUNG PEOPLE IN WEST JAKARTA, INDONESIA
}

\author{
PUGUH HARIYANTO ${ }^{1}$, JACHRIZAL SOEMABRATA $^{1}$, KOMARA DJAJA $^{1}$ \& AHMAD ZUBAIR ${ }^{2}$ \\ ${ }^{1}$ Urban Studies: School of Strategic and Global Studies, University of Indonesia, Indonesia \\ ${ }^{2}$ Center for Urban and Region Research, University of Indonesia, Indonesia
}

\begin{abstract}
A convenience store is a small retail business that stocks a range of everyday items, such as groceries, snacks, foods, confectionaries, soft drinks, tobacco products, magazines, and newspapers. However, since 2009 it has become a new space to hang out for urban youth, especially in Kemanggisan area, West Jakarta. The shift has turned a convenience store from a commercial into more public space. The aim of this paper is to understand the role of a convenience store as a public space and the behaviour of consumers in utilizing it. Data were collected using a questionnaire distributed to the people who purchase goods at a convenience store and use its area to hang out. The result of the analysis shows that a convenience store has become a space for people to interact with each other, do some chores, or spend some time alone. A variety of facilities are offered, such as affordable foods and beverages, $\mathrm{WiFi}$, toilets, and a bright place, to make a taste of urban house linger there. Moreover, in terms of its role as a destination, the convenience store is a commercial space crowded with its customers who spend their time in the lounge provided.
\end{abstract}

Keywords: convenience store, lifestyle, public space, leisure time, city, urban culture.

\section{INTRODUCTION}

A city can be described as a living place if it is able to give the people that live inside opportunities to express themselves [1]. The importance of the social public space that is naturally created by its citizen is the representative space produced by social activity such as hangout. Indonesians are common to the culture of hangout. In everyday language, the word "hangout" carries with it the meaning of "meeting up and chatting, which sometimes include smoking or drinking together." Initially, the habit has been made popular by the traditional coffee shops that have long existed throughout Indonesia.

Currently there has been a change in lifestyle as an impact of the industrial expansion in the forms of restaurants, cafes, fast food outlets, and convenience stores. Departing from the phenomenon, this paper studies the correlation between the stall (warung) culture and the convenience stores. The concept of a convenience shop in Indonesia adopts the generally known stall culture. The friendly stall model with affordable prices has shifted to the more modern form, which is in line with Indonesia's newly rising middle class, namely more global and commercial space.

It is considered commercial because basically it is a commercial space that functions as a modern place where buying and selling transactions take place and the hangout culture is one of the most desirable forms of a leisure time activity for young adults. Since the availability of sitting areas at a convenience store provides an opportunity for a hangout activity, hanging out at a convenience store can be seen as utilizing a space for a social place or placemaking. Placemaking comprises activities, management, community, and sociability. Moreover, another important factor to determine the interaction place is access (achievement) and fit (compatibility) [2]. The same concept is also offered by convenience stores throughout Indonesia for the urbanites living in big cities, especially the city of Jakarta, which is the focus of our research this time. The research was conducted in two 


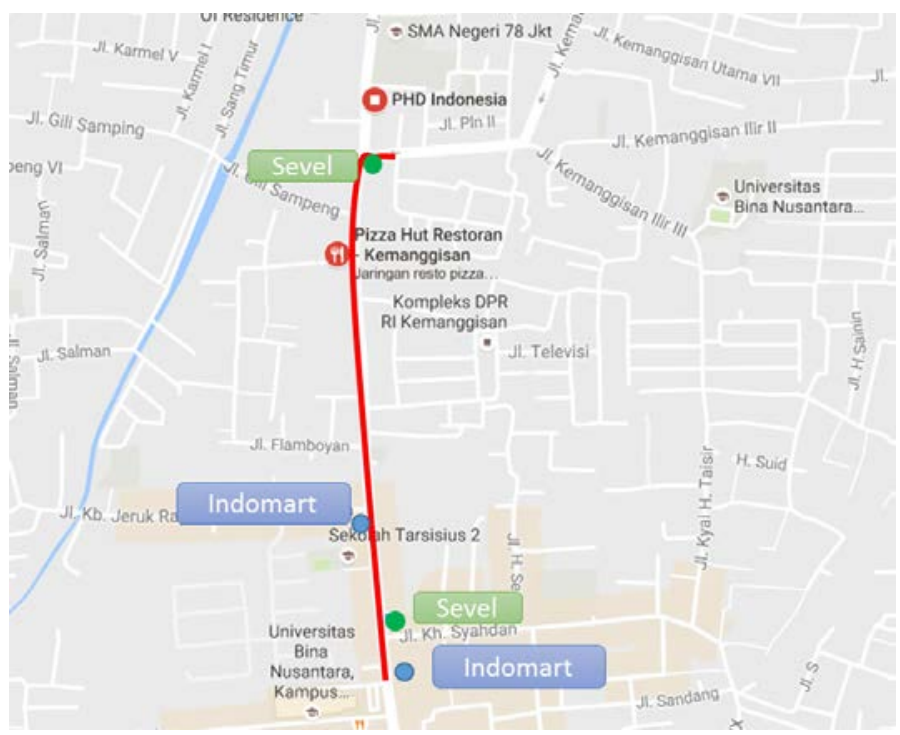

Figure 1: Kemanggisan neighborhood, West Jakarta.

outlets, namely Indomaret and 7-Eleven in Kemanggisan neighborhood in West Jakarta as seen in Fig. 1.

\section{RESEARCH OBJECTIVE}

With the seemingly unstoppable growth of convenience stores, many young urbanites make them as their hangout place. The cosy nature of the place, the availability of several facilities, and the affordable foods and drinks are the reasons for urbanites to spend their leisure time at convenience stores.

Convenience stores have some significance for urbanites: This research tries to find out how significant convenience stores are for urbanites, the reasons for them to go to convenience stores, the length of time they spend in convenience stores, and whether convenience stores address the people's needs for a space to interact.

\section{LITERATURE REVIEW}

The English word "leisure" comes from the Latin word licere, which means "to be allowed to" or "to become free." However, there are some people who believe that it comes from the French word loisir, which means leisure [3].

In his book Leisure and Recreation Management George, Torkildsen [8], explains the meaning of "leisure" as follows:

\subsection{Leisure as time}

Leisure is a spare time that someone has after $\mathrm{s} / \mathrm{he}$ has done all that $\mathrm{s} /$ he needs to do. The spare time is then used to do positive things that the person really wants to do.

\subsection{Leisure as activity}

Leisure time is used to do various activities as desired, either to rest, look for some entertainment, enrich one's knowledge, or develop skills. 


\subsection{Leisure as mood}

In this context leisure is understood as something that is related to the soul or attitude that is related to everything that deals with all matters concerning religion. This is something that comes from within oneself and not from an external factor [5].

\subsection{Leisure time as something with a broader meaning}

Leisure time is relaxation, entertainment, and self-development. In this context, someone will recover from exhaustion, escape from boredom, and be free to do something that may even lead to producing something. In this case, leisure time is defined as an expression of someone's whole aspiration in searching for happiness, a new mission, a new policy, or even new culture [6].

\section{LEISURE TIME AS A WAY OF LIFE}

Leisure time is a life that is free from pressures coming from outside one's culture and environment. With leisure time, one is able to do things that are fun and proper.

There are many locations where people can go to spend their leisure time. "The third place, the people's own remedy for stress, loneliness, and alteration seem easy to ignore" [4]. The "third place" is a place for people to relieve stress, loneliness, as well as alienation, and where one easily gets ignored. The "third place" is a place where people go to escape from their life's obligations and boredom [7]. From the two definitions, one can draw a common thread that the "third place" is space that enables people to escape or be free from their life's problems and daily routines. Additionally, it also promises relaxation, entertainment, and peace. Normally the "third place" is a place to escape from the "first place" (home) and the second place (the office).

In recent times, the "third place" is highly identical with a "shopping center". This place is used by many people to relax, escape from their daily routines, search for entertainment, and even find fresh ideas. Taking the idea of shopping center and making it into a smaller scale, the rapidly growing convenience stores have also become the "third place" for many people in the community.

\section{RESEARCH METHODS}

Data collection was gathered through interviews, direct observation, and surveys. Direct observation was carried out in June 2015 and May 2016 to observe things that convenience store's customers usually do at a convenience store in the research location.

The questionnaire was distributed to have a broader picture about the kind of people who come to the convenience store and the reasons why they go there. The aim of the questionnaire was also to find out about the background of the people who come to the convenience store in the research location, the activities they do, and the length of time they spend there.

Interviews with customers were also conducted to find out more accurate reasons why they chose to hang out at a convenience store. By interviewing visitors, a better understanding was obtained about the comfort they get from a convenience store which making them feel content when hanging out there. Interviews were conducted with visitors who came alone and in groups.

An analysis was carried out by digging for information from respondents using a quantitative approach to understand the use of convenience stores in West Jakarta. A quantitative approach was conducted to see the general trend or inclination of the use of 
convenience stores by interviewing 80 respondents who know about or have visited convenience stores located in West Jakarta.

Based on the findings, the discussion is divided into several aspects, namely purpose, comfort, time, duration, frequency, reason, colleague, and activity. The aspects will show the shaping of a new commercial space at a convenience store.

\section{RESEARCH RESULTS AND DISCUSSION}

\subsection{Purpose}

The purpose to visit a place may vary, depending on the benefits that people expects to get from their visit. Similarly, visitors who go to convenience stores in West Jakarta also have various purposes in mind. They want to find a comfortable and easy place to access as they are usually located on main roads, or offers reasonably complete facilities that affect the visitor's comfort.

The aspect of comfort is the main consideration for the visitors to come to the convenience stores $(52.5 \%)$. In addition, there are also some other aspects such as the completeness of facilities (33.7\%), cheap prices of food and beverages $(27.5 \%)$, and easy access $(27.5 \%)$. Another factor that drives many of them to visit convenience stores is the availability of facilities that make them comfortable. Indeed, convenience stores are designed in such a way that visitors are comfortable by placing tables and chairs inside and outside the outlets.

\subsection{Comfort aspect}

The many available products for visitors to choose from have led to an increasingly stringent competition in the marketing of certain products. In the end, not only do the producers or service providers have to focus on the quality of their products, but they also have to join the race in the packaging competition and providing the best service for the customers.

Recently there have been convenience stores that do not only sell products but also provide adequate and comfortable facilities for their consumers. The presence of convenience stores both directly and indirectly "threatens" the function of both the stalls and mini markets at the same time. Convenience stores sell goods in a self-service style like the mini markets, but at the same time the former ones also offer hangout places like the traditional stalls, albeit with designs that are far more comfortable for the visitors.

Results of the surveys show that $55 \%$ of the respondents chose convenience stores as a comfortable place to hang out or to gather, whereas $30 \%$ of the respondents chose cafes and the remaining $25 \%$ chose coffee stalls. The comfort they feel is associated with the facilities provided by the convenience stores for visitors, such as air-conditioned rooms, a reasonable number of tables and chairs, and other supporting facilities such as various banks' automated teller machines (ATMs).

Besides the aspect of comfort, another factor that affected the visitors in choosing which convenience stores to go to was the cleanliness of the premises and food.

\subsection{Time aspect}

This research maps the longest time spent by visitors to hang out. When respondents were asked about which day they usually come to a convenience store, they normally answered that they do not usually come based on a certain day. 
For instance, $75.9 \%$ of the respondents said they do not come to convenience stores based on a certain day, but it depends more on their desire to do so, while $16.87 \%$ come on work days (Monday-Friday), and $7.23 \%$ of the respondents said they come to convenience stores on weekends (Saturday-Sunday).

As for the choice of time for visitors to come to convenience stores, 54.95\% said they come between 19.00 and 22.00 WIB (Western Indonesia Time), 15.38\% come between 12.00 and $16.00 \mathrm{WIB}$, and $8.79 \%$ said they come between 22.00 and early morning.

In regard to the respondents' profile, the majority were between 17-25 years old, and their professions were university students and private employees: therefore, it is not surprising that convenience store outlets are always packed in the evenings because the visitors come there after working hours or lecture hours for socializing, refreshing, or fulfilling the visitors' other needs.

\subsection{Duration aspect}

The availability of facilities that are reasonably complete at convenience stores also affects the amount of time that visitors spend there. Based on the survey result, $38 \%$ of the respondents spend about two hours at convenience stores, whereas $19 \%$ spend about 1 hour, $18 \%$ spend more than three hours, another $18 \%$ spend half an hour, and $15 \%$ of them spend three hours at convenience stores.

Respondents said they could spend hours in convenience stores when they are waiting for a friend or they have an appointment. In addition to the availability of food and drinks, another reason for the consumers to willingly spend hours at the convenience stores is the free WiFi access which make them easily surf the internet. On the contrary, the factor that prevents them from spending long hours in convenience stores is the huge number of people that hang out there. For some visitors, such condition makes the place too crowded and hence uncomfortable. Many buskers that flock the stores make consumers reluctant to come to the convenience stores. Another factor that prevents visitors from coming is the limited number of electric plugs that makes it difficult for them to recharge the batteries of the gadgets they bring.

\subsection{Frequency aspect}

Another interesting thing to find in relation to the visit to convenience stores is the frequency of their visit in a certain length of time, for instance in a week or a month. It was previously mentioned that the length of time spent by visitors at convenience stores is between one and three hours. When questioned further, the visitors mentioned that the length of time they spend at the outlets do not always correlate with the frequency or the number of their visit.

When respondents were asked about the frequency of their visit to convenience stores in a week, $44.83 \%$ of the respondents answered three times, $29.31 \%$ answered two times, $14.66 \%$ answered four times, $8.6 \%$ answered more than four times, and $2.59 \%$ answered only once a week. When accumulated, the respondents who said they come to convenience stores three times or more in week are $68.1 \%$.

During the interviews with open questions, another option chosen by respondents in terms of the frequency of visit to convenience stores is monthly, which means that the informants might come more than once in a month. One informant mentioned that he comes once or twice in a month. Two other informants said that on average they come twice in a month. 


\subsection{Colleague aspect}

With whom do visitors usually come to a convenience store? Normally that depends on the purpose of the visit to the place. The survey result shows that the majority of visitors going to convenience stores come with friends. It reflects the fact that convenience stores are a cool place for young adults to hang out and gather with their friends or co-workers.

The survey result shows that 71 times $(71.72 \%)$ the respondents stated that they come with friends, whereas 13 times (13.13\%) come unaccompanied, 10 times $(10.10 \%)$ come with a business partner or co-worker, and 5 times $(5.05 \%)$ come with their families. The result shows that the issue of with whom the visitors usually come to a convenience store depends on their needs to go there.

\subsection{Reasons for visit aspect}

Reasons for visitors to come to a convenience store, as with any other place may vary. The main reason is because they want to interact with their friends or they are comfortable with the outlet. Furthermore, it is certainly related to the consumptive needs, such as buying food and beverages.

The results shows that 52 times $(53.06 \%)$ respondents said they come to a convenience store because it is a nice place to interact, 20 times (20.41\%) the respondents said because the location is good, and 20 times $(20.41 \%)$ the other respondents said because it is a nice place to relax, whereas 6 times $(6.12 \%)$ the respondents said because it is a green open space, there is a limited number of parks in the city, or it is not very comfortable to spend time at those parks.

Besides the consumption issue, when interviewed or given open questions, an informant claimed that he visits convenience stores as a form of expression, a way for him to follow the up-to-date trend currently happening.

\subsection{Activity aspect}

What activities do visitors do when they come and hang out at a convenience store? Based on the survey, 52 times $(39.1 \%)$ the respondents stated that the activity they do at a convenience store is chatting with friends, whereas 34 times $(25.56 \%$ of the respondents) said they finish their work or did lecture tasks, 17 times $(12.78 \%$ of the respondents) answered relaxing and using the internet, 10 times (7.5\% of the respondents) said killing time, and 3 times $(2.56 \%$ of the respondents) said reading a book.

\section{DISCUSSION}

\subsection{Convenience stores fulfilling urbanite's needs}

Like people in any other big cities, people in Jakarta are extremely busy. They need a public space for refreshing or taking a short break from their routine. Attributable to the easy access and comfort it provides to visitors, a convenience store is considered by the general public as an alternative place to fulfil the needs of city dwellers. Convenience stores that offer facilities such as tables and chairs equipped with free WiFi and air-conditioned rooms are perfect places as alternative places to hang out for Jakarta dwellers.

Previously people in Jakarta used to hang out in cafes or stalls, but now they have an alternative, which is convenience stores. The adequate facilities, the easy access because of 
their strategic location on the main roads, and the prices that are generally cheaper than the prices of foods and drinks people buy when they go to cafes and not much more expensive than the prices at street stalls make convenience stores more alluring for people in Jakarta, especially the young adults, to hang out.

The presence of convenience stores fulfils the needs of urbanites for a place where they can shop for goods without having to go to a mall. People may fulfil their shopping needs here both directly and indirectly. In this case, shopping directly means they can come to a convenience store outlet and buy goods they need at that place, whereas shopping indirectly means they can do online shopping through their gadgets with the availability of the free internet connection there.

\subsection{The addition of a convenience store as commercial space}

Convenience stores are a current trend for the capital city's young adults. One can find convenience store outlets almost in every place in the capital city, and the majority of them are always fully packed with visitors at rest breaks and night. However, has the number of the currently existing convenience stores already met the needs of the consumers for cool places to hangout, or do the consumers even feel that more convenience stores are needed?

The result of the interviews with the informants shows that several informants stated that the number of convenience stores in their neighbourhood needs to be added. However, according to them the addition should be based on two categories: an addition in the number of the convenience stores and an addition that focuses more on adding the facilities in the existing ones.

On the other hand, some other informants stated there is no need to add the number of convenience stores in their neighbourhoods, and in average the reason given is that the current number was already adequate enough. Furthermore, there are even some who stated that the current number of convenience stores is too high, while some others think that there is no need to add more convenience stores since the current number is sufficient. Instead, what needs to be done is to reorganize the existing convenience stores so that they do not disturb the environment of the residential areas nearby.

\subsection{Hangout activity as a form of the shift of commercial space}

For the majority of the young adults, hanging out in certain places like malls, parks, cafes, or others has become a lifestyle and those places have become spaces for them to socialize. In addition to the above-mentioned places, the currently developing trend for them is to hang out at convenience stores. Convenience stores have been designed in such a way as accommodate the visitors to feel pampered and hence spend longer time there. However, this research also tries to find out, aside from convenience stores, which other places that are considered comfortable places to hang out. Each individual has a different way of hanging out there. The majority of the activities undertaken when people hangout involve sitting down, chatting, joking, and sharing snacks.

The trend of utilizing convenience stores as a place to gather and spend time is another reason. In the end hanging out and gathering in convenience stores offer a new identity for the visitors. By going there, they feel that they belong and become cool people. The previously mentioned conditions show the shift of space within convenience store's commercial space. Transaction activities take place because there is a purpose of utilizing the place for hangout activities. The space that was previously commercial in nature has then shifted to be a place that is more public with the hangout activities. 


\subsection{Placemaking in the formation of convenience store's commercial space}

Hangout activity that is performed at a convenience store is a signification of the commercial store. Visitors as a group of individuals have direct participation in utilizing the commercial space through their activities. The activity has become a process of how visitors interpret the commercial space as a place where they usually live providing comfort when they do their activities there. For instance, visitors have the freedom to arrange the tables and chairs in the convenience store's commercial space. Such condition signifies that there is a process of signification to turn the space into a place. Hangout activities in the commercial space of every convenience store have turned it into a place with an additional meaning for its visitors.

Based on the result of the observation and survey as previously explained, on average, visitors can spend more than three hours there and, in the end, they choose convenience stores as their hangout location. Furthermore, the process of placemaking is also signified by stages of the flow of activities while hanging out in the provided sitting area. In general, visitors do not only buy and sit, but they also seem to repeatedly leave their seats to buy more food and drinks, and return to their seats with their new purchase.

Moreover, based on the observation result, male visitors tend to hang out outside more because they choose to hang out while sitting down smoking. The activity is a process of signification that is carried out by the majority of the male visitors who do hangout activities in the commercial space of a convenience store. However, something different is indicated by the female visitors. They generally come in groups and sit in a circle to enable them to chat more easily. In addition, female visitors also seem to sit inside more.

Based on the explanation above, it is fair to say that through their hangout activity visitors of convenience stores have performed placemaking. It is through such activity that visitors perform the process of signifying the commercial space of a convenience store, which is done by taking over the activity that is happening in the space. For example, placemaking is performed when visitors can freely rearrange the chairs and tables to turn the place to make it more comfortable for them.

The shift that has occurred at a convenience store has not only turned a commercial space into a more public one, but the process of signification has also been carried out by the majority of the visitors turning it into a destination, especially a destination for hanging out.

\subsection{The typology of hangout in a convenience store}

Based on the observation, it is found that visitors of the 7-Eleven outlet in Kemanggisan mostly come by car. By observing the cars, they drive, it can be deducted that they come from established economic background. They also wear nice and neat clothes. Even at night time between 19:00-21:00 WIB they still wear office clothes. They come either unaccompanied or with some friends.

At the Indomaret outlet in Batusari, however, the situation is different. Here most visitors come by bike. Their activity is also more homogenous, which is having a chat with friends, or if the visitor is unaccompanied, s/he will only enjoy the drinks and food. Those who come alone usually open their cell phone. Very rarely do they come and then open their laptop. Their clothes are also ordinary, and there is no indication that they are office workers or students.

Meanwhile, visitors of the Indomaret outlet near Bina Nusantara (Binus) University, which is about 300 meters away from the Indomaret at Batusari intersection, is very 
different. At the outlet near Binus University the majority of the visitors are students. In terms of appearance, they are very different compared to the visitors of the outlet at Batursari intersection. Despite the fact that they come by bike, their fashion style is different.

A similar condition occurs at 7-Eleven outlet in front of Binus University. The majority of the visitors are also students. The shape of the two places is also almost similar. Both are two-storied buildings. The first floor is for the merchandise whereas the hangout area is on the second floor. Cable TVs are provided in both floors. With such facilities, certainly the place is more crowded on weekends because visitors want to watch the European Football, which is not broadcast for free by Indonesian television stations.

\subsection{Conclusion}

Hangout activity is a process of signification that is performed by visitors on the commercial space of convenience stores. Hangout activities in commercial space that are carried out for several hours provide visitors with an opportunity to signify the commercial space.

Placemaking in the commercial space of convenience stores is performed by visitors through their hangout activity that dominantly takes place there. The creation of placemaking in the commercial space through hangout activities has made convenience stores become visitors' destination to hang out. Convenience stores becomes hangout destinations that are visited by many individuals from different walks of life. In other words, business has fulfilled the needs for relaxing and trendy spaces. This is reflected by the fact that the majority of the respondents stated that they go to convenience stores because the places are comfortable to spend time to interact with their colleagues.

\subsection{Recommendations}

The rapid growth of convenience stores still needs to be controlled by the government. In our opinion, to provide a fair chance for small and middle scale businesses to grow, the government needs to obligate convenience stores to partner with small and middle scale businesses. For instance, the government can issue a regulation that necessitates convenience stores to sell products of small and medium businesses. It could be snacks or other kinds of food.

The government also needs to extend the green open space or parks. Based on the survey, some respondents mentioned the importance of parks as a space for interaction for urbanites. Indeed, a convenience store has become another option as a place to conduct one's activity; however, dwellers also need a comfortable park for them to kill their time. The limited number of parks is one of the reasons why many people go to convenience stores.

\section{ACKNOWLEDGMENTS}

This work is supported by Internationally Indexed Publicity Grant for Final Assignment of Post-Graduated Student, Universitas Indonesia, Grant funded Universitas Indonesia Contract no. 2154/UN2.R12/HKP.05.00/2016

\section{REFERENCES}

[1] Lefebvre, H., The Production of Space. Blackwell Publishers Inc., Massachusetts, 1991.

[2] Lynch, K., Good City Form. Massachusetts. The MIT Press, 1984. 
[3] Januarius, A., Study Tingkat Kebosanan Dalam Waktu Luang pada Mahasiswa Baru Universitas Kristen Petra Surabaya. Surabaya, 2011.

[4] Oldenburg, R., The Great Good Place: Cafes, Coffee Shops, Bookstores, Bars, Hair Salons, and Other Hangouts at the Heart of a Community. USA: Marlowe \& Company, 1999.

[5] Pieper, J., Leisure the Basis of Culture an Integration of the Contemplative and Active Live. Pantheon Books Inc., New York, 1999.

[6] Dumazedier, J., Current problems of the sociology of leisure. International Social Science Journal, 4(4), 522-553, 1960.

[7] Wechsberg, J., The Viennese Coffee House: A Romantic Institution. Gourment, 12:16, 1966.

[8] Torkildsen, G., Leisure and Recreation Management, Routledge, 1999. 